\title{
Family management ofchildren who experience sickle cell disease: a qualitative study
}

\author{
Manejo familiar de crianças que vivenciam a doença falciforme: um estudo qualitativo
}

Manejo familiar de niños que experimentanenfermedad decélulas falciformes: um estúdio cualitativo

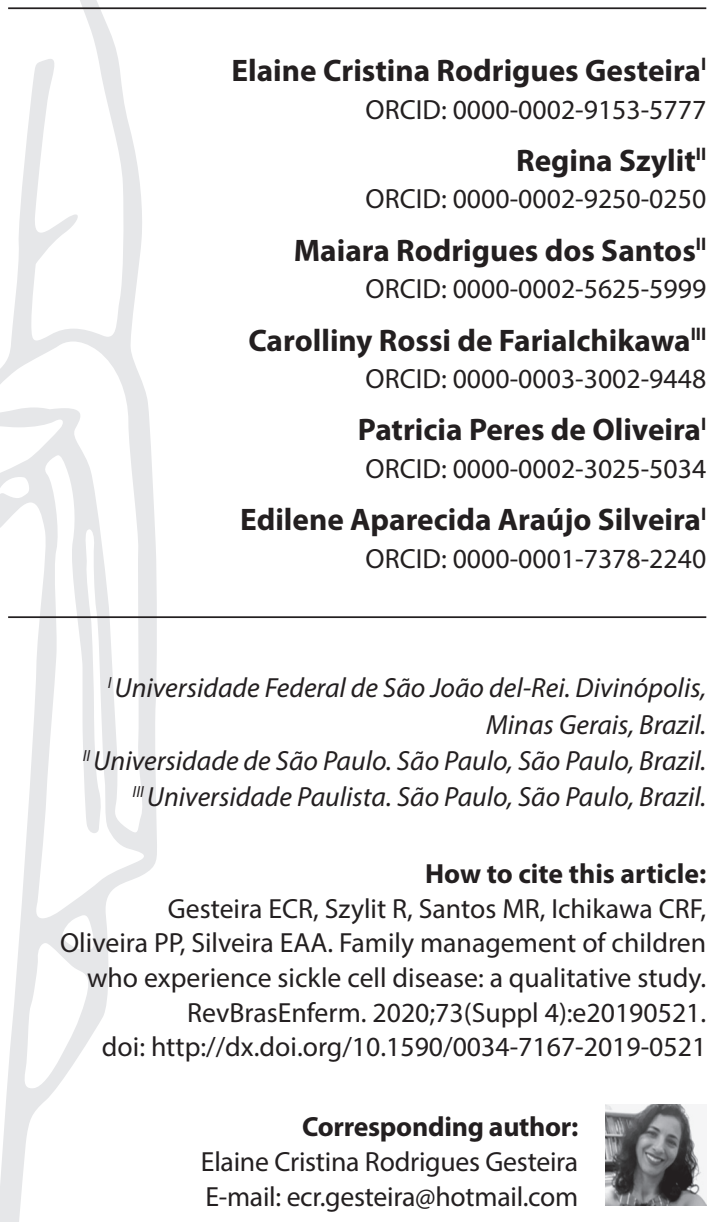

EDITOR IN CHIEF: Antonio José De Almeida Filho ASSOCIATE EDITOR: Hugo Fernandes

Submission: 07-10-2019 Approval: 02-10-2020

\begin{abstract}
Objective: to know the family management experience of children with sickle cell disease in the light of the Family Management Style Framework. Methods: a qualitative case study carried out between September/2015 and July/2016 with 12 members of eight families registered in a blood center in Minas Gerais. The semi-structured interviews were recorded, and the data were analyzed and interpreted by the hybrid model thematic analysis. Results: three management styles were identified: five families in the accommodating style; two families in the struggling style; and only one family in the enduring style.lt was noted that empowerment was paramount in the acquisition of skills and abilities to care for these children. Final considerations: family management knowledge of children with sickle cell disease provided a reflection on nurses' role in supporting, orienting and encouraging the empowerment of these families aiming at the search for comprehensive care.

Descriptors: Family; Child; Anemia Sickle Cell; Pediatric Nursing; Primary Health Care.
\end{abstract}

\section{RESUMO}

Objetivo: conhecer a experiência de manejo familiar de crianças com doença falciforme à luz do referencial teórico Family Management Style Framework. Métodos: estudo de caso qualitativo, realizado entre setembro/2015 e julho/2016 com 12 membros de oito famílias cadastradas em um hemocentro mineiro. As entrevistas semiestruturadas foram gravadas e os dados analisados e interpretados pelo modelo híbrido de análise temática. Resultados: três estilos de manejo foram identificados: cinco famílias no estilo accommodating (acomodando); duas famílias no estilo struggling (lutando); e apenas uma família no estilo enduring (tolerante). Frente aos estilos, notou-se que o empoderamento foi primordial na aquisição de habilidades e capacidades para o cuidado dessas crianças. Considerações finais: o conhecimento sobre o manejo familiar de crianças com doença falciforme propiciou a reflexão sobre a atuação do enfermeiro no apoio, orientações e estímulo para o empoderamento destas famílias visando à busca de um cuidado integral.

Descritores: Família; Criança; Anemia Falciforme; Enfermagem Pediátrica; Atenção Primária à Saúde.

\section{RESUMEN}

Objetivo: conocerl a experiencia de gestión familiar de niños con anemia falciforme a la luz del marco teórico Family Management Style Framework. Métodos: estudio de caso cualitativo, realizado entre septiembre/2015 y julio/2016 con 12 miembros de ocho familias registradas e nun centro de sangre en Minas Gerais. Las entrevistas semiestructuradas fueron grabadas y los datos analizados e interpretados por el modelo híbrido de análisis temático. Resultados: se identificar ontres estilos de gestión: cinco famílias e nel estilo accommodating (complacente); dos famílias em el estilo struggling (lucha); y solo una família e nel estilo enduring (tolerante). Frente a los estilos, se observó que el empoderamiento era primordial en la adquisición de habilidades y destrezas para el cuidado de estos niños. Consideracionesfinales: el conocimiento sobre el manejo familiar de los niños con enfermedad de células falciformes llevó a una reflexión sobre el papel de La enfermera en el apoyo, orientación y estímulo del empoderamiento de estas famílias con el objetivo de buscar una atención integral. Descriptores: Familia; Niño; Anemia Falciforme; Enfermería Pediátrica; Atención Primaria de Salud. 


\section{INTRODUCTION}

Sickle cell disease (SCD) is an autosomal recessive hemoglobinopathy of genetic origin, in which sickle hemoglobin arises from a variation of the hemoglobin A's ( $\mathrm{HbA}$ ) beta globin (HBB) gene. This gene mutation (HBB) occurs by replacing the nitrogenous base adenine with thymine, which leads to the modification in the sixth codon of this gene and the replacement of glutamic acid by valine in the chain. Thus, sickle hemoglobin $(\mathrm{HbS})$ disrupts the $\mathrm{HbA}$ molecule, and in conditions such as circulatory delay and low levels of oxygenation, it triggers the polymerization process leading to the deformation of erythrocytes, which become strained ${ }^{(1)}$.

Parents transmit the altered gene to their children, and children receive the modified gene in double dose of $\mathrm{HbSS}$, the most serious form of $S C D$, that is, sickle cell anemia. Other hemoglobinopathies, such as $\mathrm{HbC}, \mathrm{HbD}, \mathrm{HbE}$ and beta-thalassemiamay appear in combination with $\mathrm{HbS}$, which present similar clinical symptoms and that form $\mathrm{SCD}^{(2)}$.

Sickle cells are less flexible when compared to normal cells. In this way, they join the vascular endothelium causing an inflammatory process that, with the local increase of erythrocytes, granulocytes, monocytes and platelets, originates the vasoocclusive phenomena (hemolysis, venous stasis, tissue hypoxia). As a consequence, they affect different organs, causing the following clinical manifestations: painful crises, hemolytic anemia and lesions in different systems $s^{(1)}$.

SCD is detected by the Neonatal Screening Test, which aims to identify cases, confirm the diagnosis and direct treatment to the levels of Primary and Secondary Health Care. According to data from the Brazilian National Newborn Screening Program, the incidence of SCD is concentrated in the state of Bahia, where for every 650 children born alive, one has the disease, followed by Rio de Janeiro, in the proportion of 1:1,200 live births, in addition to the states of Minas Gerais, Pernambuco, Maranhão, and Goiás, with 1:1,400 live births. In these states, there is a greater concentration of people of African descent that originally inherited and disseminated the sickle cell trait and the disease ${ }^{(2)}$.

Due to a set of actions aimed at treatment, the survival of patients with SCD has improved, reducing morbidity and mortality and increasing life expectancy. Therapeutic advances include prophylactic use of penicillin in children under five and access to special immunobiologicals, medications for routine use, such as folic acid and hydroxyurea. In cases where children do not respond to pharmacological treatment, blood transfusions are indicated ${ }^{(3)}$.

However, the only possibility of a cure for SCD is hematopoietic stem cellstransplantation, indication of which is restricted to severe cases in which patients have at least two episodes of stroke, but the risk-benefit ratio is analyzed judiciously, in view of the possible complications during the procedure's preparation period and duration ${ }^{(4)}$.

Although it is recognized the importance of advances in the treatment of $S C D$, it is a constant challenge for families to live with children with a chronic disease in their daily lives. They suffer an impact on their routines leading them to intense physical and emotional stress, with the family functionality being altered by the demand for necessary care for the sick child, including tests, blood transfusions, medications, dietary control and restrictions related to activities physical ${ }^{(3)}$.
In this sense, families that have a child with SCD face similar situations around care and possible complications arising from this condition. However, family management, a concept that refers to the way in which the family as a unit, responds to chronic illness ${ }^{(5)}$, and can be faced in different ways. Thus, each family presents its management style, with typical behaviors that fluctuate over time in the face of the disease experience.

With this view, seeking to understand the daily lives of these families and the role of nurses in the promotion of care, an integrative literature review was carried out that pointed out the scarcity of national productions on the experience of families in child care in these conditions ${ }^{(6)}$. In this perspective, the following question arose: how does the family of children with SCD manage care in their daily lives?

Thus, it is necessary to know and identify the family management styles for a specific role of nurses as members of a multidisciplinary team, which is resolute in the support, guidelines and referrals necessary for the continuity of care. Since SCD is a chronic disease, favoring personalized care, according to the family's demands, will imply minimizing the stressful effects generated by the disease in the family. In addition, it will strengthen family members, despite the disease, to seek the balance of their routines, benefiting the achievement of better living conditions for these children.

\section{OBJECTIVE}

To know the family management experience of children with SCD in the light of the FMSF.

\section{METHODS}

\section{Ethical aspects}

Resolution 466/2012 of the Brazilian National Health Board (Conselho Nacional de Saúde) guided the study. The study was approved by the School of Nursing's Research Ethics Committee at the Universidade de São Pauloand by the co-participant institution Fundação Centro de Hematologia e Hemoterapia de Minas Gerais (FundaçãoHemominas). All participants signed a consent form.

\section{Type of study}

This is a case study ${ }^{(7)}$ with a qualitative approach ${ }^{(8)}$, which used the theoretical framework Family Management Style Framework ${ }^{(5)}$, which allows assessing how the family, as a unit of care, responds to the chronic illness of one of its members, through the conceptual components: situation definition, management behaviors and perceived consequences.

Situation definition refers to the meanings attributed by the family to the management experience, being composed of the dimensions: children's identity, view of the condition, management mentality and parental mutuality. Management behaviors are taken over by family members in different situations imposed by chronic disease. Its dimensions are the philosophy on parenting and management approach. The perceived consequences are the current and expected results by the family in the daily 
disease management, identified by the dimensions: family focus and future expectations.

As a method, a case study was used, which allows understanding complex social phenomena, based on real life events ${ }^{(7)}$. This study followed the Consolidated Criteria for Reporting Qualitative Research (COREQ), recommended for study design preparation and analysis of data in qualitative research.

\section{Study setting}

The study was carried out at the home of families registered in a blood center located in the state of Minas Gerais, where patients with hemoglobinopathies, transfusions and therapeutic bleeds are seen, being a reference in the Midwest of Minas Geraismacro-region.

\section{Data source}

The data were collected through semi-structured interviews, carried out in-depth, associated with the construction of genograms, ecomaps and document analysis, which, triangulated, comprised the families' case studies.

The interview scripts followed the dimensions of the conceptual components of the FMSF: definition of the situation: the child's daily life/parents' performance in handling daily care/difficulties in caring for the sick child/mutuality of the couple; management behaviors: how care for the sick child has been carried out in the family routine/as was the daily routine before the diagnosis of the disease/how was the routine after the discovery of the disease; perceived consequences: care of the sick child and its interference in other family routines/the child's future and family life.

Participants were eight families of children with SCD registered in the study setting. Families that met the inclusion criteria: being parents or grandparents caregivers of one or more children with SCD and being families at different stages of the family life cycle were selected. The excluded were families without an updated address and/or telephone number.

The participating families were identified by numbers, followed by the initial letters of the children's names, in order to preserve their identities, as described: family - $F\left(n^{\circ}\right)$ and child - C (initial of the name) and interviewed family member.

Of the selected families, two refused to participate on the grounds that they were unavailable. First contact with these families was by telephone. If so, interviews were scheduled and it was confirmed which family members would participate. The agendas followed the availability, date and time that best suited the participants. Following the continuous analytical process throughout the collection, the speeches of participants became repetitive, not generating new information - reaching the saturation ${ }^{(8)}$.

\section{Data collection and organization}

Data collection took place between September 2015 and July 2016 , carried out by the main researcher, who had no previous contact with these families. A total of 24 interviews were conducted, with 17 individual interviews being conducted, four interviews with two couples, three interviews with another family member present. In five families, the interviews were conducted only with the children's mothers. All interviews took place at the homes of these families, with 12 family members being interviewed, according to distribution: eight mothers, three fathers and a maternal grandmother.

During the interviews, the participating family members were asked that the child was not at home at the time of the interviews, in order to preserve it emotionally. The choice of the private environment of the house was chosen by the participant, and the interviews were conducted only after explanations and signing a consent form.

Regarding children with SCD, five were male and five female, all had siblings, with the exception of one child, who was an only child. In two cases, families had more than one child with the disease. In the first meeting, the open interviews were directed with the guiding question "Tell me, how has the family's daily life been since the child was diagnosed with SCD?". This initial question allowed us to know, partially, the trajectory of families in the management of children with SCD. In the second meeting with family members, semi-structured interviews were conducted according to the FMSF framework, seeking to understand the components: how the family defines their situation, the identification of management behaviors and the perceived consequences of the daily care of children with SCD. In the third meeting with family members, the information obtained from the families was validated. The average duration of each meeting ranged from 52 minutes to 1 hour and 15 minutes. All interviews were recorded on audio, and were transcribed in full after their completion.

\section{Data analysis}

The data analysis process was guided by the hybrid model thematic analysis ${ }^{(9)}$. In this process, there is a search for themes that are more important for the description of the phenomenon. The identification of themes occurs through the careful reading and rereading of the data that will become the categories for analysis. The hybrid model uses deduction from predetermined codes, that is, a template that, in the present investigation, was developed using the theoretical framework FMSF, in line with an inductive approach based on the data.

In the analytical phase, the text was coded, combining the codes of the template and the inductive codes generated by the initial transcriptions. Then, the codes and possible themes were brought together, which were grouped and examined rigorously, in order to represent the reality of the initial analysis and the designated codes characterizing the interpretative phase. The analysis was carried out by two researchers with experience in qualitative research, independently. The discrepancies were discussed with a third researcher, to guarantee the validity of the interpretation.

\section{RESULTS}

The main results in the family management experience of children with SCD were evidenced with the research, according to the conceptual components and dimensions of the FMSF model. 
The definition of the situation, an initial component of the FMSF, highlights the following dimensions: the identity of children, considering the role that the child plays in family life; their view of the child's illness; the management mentality characterized by facilities and difficulties; and the mutuality that exists between the couple and family members in conducting the management.

In describing their children's identity, families highlight normality as the view they want to preserve of children, despite recognizing limitations and vulnerabilities imposed by the disease that influence their identity. However, they are able to identify their children's autonomy in terms of how the child can cooperate with their own treatment.

[...] and we see her as a normal girl, because we can't let that show her, but we know she has limitations. Do you understand? (F1-CV-Grandmother)

[...] he does everything that a normal child does, without the sickle cell, but he cannot do much physical exercise because he gets tired easily. (F8-CN-Mother)

She is a child that when does a blood test, she does not cry. She gives the arm. She is a child that she will have a transfusion: "Mommy, today is thetransfusion day, right? So, let's go! (F1-CV-Mother)

The families' view of the diagnosis was impressive. Family members suffer an impact at the beginning of the diagnosis, going through disbelief and despair until they understand better about the disease, a period accompanied by guilt for the family's genetic condition and fear of the complications that SCD can cause. In addition, they recognize that SCD is a serious condition, difficult to manage after discovery, and that there may be possible complications with injuries to different organs, such as acute chest syndrome, lower limb ulcers, stroke, eye complications, priapism, splenic kidnapping, among others that can lead to the premature death of children.

\begin{abstract}
My despair was really great, [...] for not knowing how I was going to do with it [...] how was I going to act in relation to a disease that is not known, and with the first son, do you go through this? You imagine everything perfect, the perfect child, [...] so, I was very desperate [...]. (F2-CE-Mother)
\end{abstract}

[...] and until 2 years old, 2 and a half years old, she didn't feel anything, [...] does she really have that? I had never felt anything, but until [...], started to feel pain in my wrist, hand, and elbow ever since. Then when it started, we were scared, we didn't know anything, then we started to research, go online [...]. (F1-CV-Father)

[...] when it touches us, it [illness] is difficult and also the fault. Do you think it is a problem that the father originated for the son? (F3-CJO-Mother)

In the management mentality dimension, difficulties and facilities in following the therapeutic regimen were identified. Family management around care such as healthy eating, adequate hydration and control over physical activities prevents the worsening of crises, and in the long run, this routine is incorporated by the family, considered as an easy way to manage the disease in everyday life. On the other hand, the existing difficulties are related to financial aspects, which change family dynamics, such as: absenteeism in the job to care for sick children, informal jobs of one spouse, especially the maternal figure for the comprehensive care of the sick child.

Families also highlight another challenge related to health team care in the different spaces of the Health Care Network, as they realize that some professionals have doubts about the treatment and management in view of the clinical manifestations and complications of SCD.

So, we buy his juice, fruit to make juice [...] there is no shortage of juice in the refrigerator. I give him water, food. E. does not eat anything fat, he eats vegetables, beans, rice, and meat is not exaggerated [...]. (F2- EC-Mother)

[...] we had to borrow money to pay for buses, antibiotics are very expensive, there are antibiotics that are not on the network [public] I have to buy, because I can't wait to get there, do you understand? [...] medicines are not cheap I think so, that our assistance for all children with sickle cell anemia is very lacking. (F4-CL-Mother)

He started walking [pause] and when he started walking he hada foot and toe crisis [...] I went to the ECU and the doctor didn't know how to deal with the situation, he thought that I had dropped my son and he was screaming in pain and I had to call Dr. E. [blood center]. And she called the hospital and talked to the pediatrician about how to treat. (F4-CL-Mother)

In the last dimension of the component, situation definition, the parental mutuality was identified in the shared perspectives of parents about their child, disease and management.

Much more united, certainly [...] it turns out that we are like this, we lean on each other because we are very afraid of losing him, when he gets sick, we are like this, very close, very close to him [...]. (F7-CP-Mother)

[...] united, because it is one embracing the cause of the other, giving support. (F6-CJ and CJE-Mother)

The second conceptual component of the FMSF highlights management behaviors with their dimensions: philosophy on parenting and management approach.

Philosophy is the search for a family of specific strategies based on values, goals and priorities that guide the management of the disease. Meanwhile, the management approach refers to the extent to which this family and the child have developed a routine. Parents, according to their beliefs and priorities, seek partnerships, access benefits from Social Security and resort to supplementary health, seeking to establish a philosophy based on the maintenance and well-being of children with SCD.

[...] at school, they know that you have to pay more attention. Like this case that happened to her regarding ischemic attack, I'm sure that if she had been in another school [referring to the public school], they wouldn't have noticed [...]. Whyis there a classroom with 40 students and a child with anemia? She wouldn't have the necessary attention, understand? So, today she is in a private school. (F1-CV-Mother) 
So, I at least fight, if you tell me that G. has a right, [...] / run behind until I see if she really has it. Because here, [in the city] G. is the only child retired due to sickle cell anemia.(F5-CG-Mother)

[...] tests are expensive, delay is very long, so, [...] as he has this problem, he cannot wait so long [...] how do I will I wait for SUS? There's no way, so I have to pay [...] we prioritize this. (F4-CL-Mother)

Faced with the need to incorporate new routines, the different management approaches that these families take are recognized, as attempts to keep the child close by, adjustments to the best routine for the family that can meet the needs of the child with SCD. Mainly guidelines, so that all family members know how to recognize signs of complications of the disease that need assistance in secondary and tertiary care. It is noted that all families had their daily lives altered by the disease.

The disease interferes in my life, because I stopped working to take care of him, so it only interferes a little in my profession, because I have none. (F2-CE-Mother)

Care has been modified, you know, [...] I always try to be very aware of his food, the medications he needs [...]. (F7-CP-Mother)

In the last conceptual component, perceived consequences, the dimensions stand out: the focus of the family, the parents evaluate the family dynamics and its functionality in detriment of the daily management of the chronic disease; and future expectations, in which parents assess the implications of the disease for their child and the future of their family.

In this study, the focus of families is on controlling the disease and stimulating self-care for children. In the parents' evaluation, the routine becomes adjusted with the time of management.

But today it is quiet, if you came, then 5, 6 years ago it would be very difficult, [...] today we already have ... some knowledge, little, basic, but today it's ok.(F4-CL-Father)

[...] I try to talk to L. as much as I can, I try to show him to understand, because if I ever missed him, even L. even knows how to say everything he went through everything he lived [...] I don't want my son to grow up thinking that he can't do anything, that he can't go anywhere because of this disease, I want him to grow up knowing that he has the disease, that he can treat, but that he can live normally. (F4-CL-Mother)

Future expectations are permeated by feelings of doubts and uncertainties in the face of the unpredictability of the disease, with its crises and complications. In addition, there is concern about the transition to adolescence and the stigma of the disease due to its Afro-descendant origin.

[...] L.'s future, [pause] the fear! L. can sleep in one way and wake up in another, and what I ask of God is to allow me to live until my son is an adult, because he is older and he will be able to take care of himself. (F4-CL-Mother)

I only ask God to leave her with me indefinitely, that's all. Her future I don't even want to think about [...] I want to live today, tomorrow and that's it. (F5-CG-Mother)
[...] myson's future ... passing from child to teenager ... we don't know [...] how his organism will react [...] ifl'm going having to look for a doctor now [...] or if I'm going to spend more time with the pediatrician, [...] and discrimination [pause] [...] we are already creating him with a very open mind to not even accept being discriminated against, because he has his rights, so he has to run after his rights. (F7-CP-Mother)

It should be noted that, among families, three management styles were identified: five families in the accommodating style, that is, family members seek to maintain normality and, daily, fight for the adjustment of care in their routine, confident in the management of the disease; two families in the style struggling, families in which the parental conflict interferes in the management of the disease and the mothers dissatisfied with the participation of the spouse; and only one family in the enduring style, where family members have confidence in their disease management capacities, however they reveal that overprotection is an attitude present in the management of children with SCD.

\section{DISCUSSION}

The deductive analytical process guided by the theoretical model of the FMSF allowed to know the functioning of the family when dealing with children with SCD. Initially, in the definition of the situation, parents attribute to their children characteristics similar to those of other children of the same age, considering them normal. This identification is probably based on the invisibility of SCD, which only becomes evident from the first clinical manifestations, around the child's six months of life. This mechanism occurs because even in this age group there is a high concentration of fetal hemoglobin $(\mathrm{HbF})$ in the bloodstream, which, due to its increased affinity for oxygen, prevents the phenomenon of sickling ${ }^{(1)}$.

From the first experience of the family with the symptoms, when the disease becomes visible, the parents realize the need for new articulations in the family to dedicate to the child who will need more intense $\operatorname{care}^{(3)}$. In this context, family members start looking for ways to avoid the onset of new crises, limiting their activities due to the focus on their vulnerabilities. However, throughout the management experience, children start to develop skills and abilities in the knowledge about their disease, contributing with their own care, this cooperation favors the prevention of disease complications and contributes to the therapeutic treatment ${ }^{(10)}$.

Considering the view of families facing the child's diagnosis, it is noted that SCD, like any other chronic disease, is impactful and threatening. The diagnosis is difficult to understand, generating indignation and frustration, because the idealized child throughout pregnancy is not the one they now have. This fact triggers a rupture in their life trajectories ${ }^{(11)}$.

These families, after diagnosis, receive the first information about the disease and its treatment by blood centers. However, although they receive guidance through a multidisciplinary service, it is clear that virtual networks, specifically blogs and associations of individuals with SCD created in sites, constitute means of communication frequently accessed by them. In this regard, an international study ${ }^{(12)}$ confirmed this search by patients with chronic disease and their families, guiding the relevance of creating sites on the internet that are reliable, so that users 
have a channel guidance and, above all, sharing with other cases similar to yours, setting up a support system.

In this dimension about the cause, severity and prognosis of SCD, families build their beliefs and establish strategies for family management.However, the role of the multidisciplinary team in this process is healthy, specifically nurses for excellence in care, who needs it regardless of the place of acting in the Health Care Network, being able to be welcomed, establishing bonds and knowledge about the functionality of these families, in order to propose individualized interventions that can favor them in coping with the disease ${ }^{(13)}$.

Another aspect to be considered in the view of these families, is the fear of premature death of children. It is undeniable the recognition that the unpredictability of the disease generates in these families a suffering management marked by sickling crises and recurrent hospitalizations ${ }^{(3)}$. In view of the identity and vision of these families, it is identified that their management mentalities are focused on following the effective therapeutic regime ${ }^{(14)}$. In this sense, the family dynamics changes, and in the search for adjustment, the parents organize themselves in view of the needs of caring for the child and labor issues.

In this context, three families in the study were able to count on the support of employers, facilitating a better financial condition, however the five families that did not have this support reported difficulties in accessing tests and medications not available in the Health Care Network, which although they are provided by the Brazilian Unified Health System (SUS - Sistema Único de Saúde), there are periods of delay in distribution. As children cannot wait due to the risk of complications, families need to defray expenses, with low family income making it difficult to conduct the therapeutic itinerary ${ }^{(15)}$.

It is worth mentioning that although there was a therapeutic advance in the management of SCD, the great challenge of preventing the spread of the sickle cell trait among populations and the complications of the disease still remains, since many patients only discover that they have the trait when they are blood donors, or even, unfortunately when a child is born with $\mathrm{SCD}^{(16)}$. It is worth noting that since 1996, the Brazilian National Human Rights Program included the recommendation to implement the national policy for people with SCD, which leveraged the Brazilian actions of detection and monitoring with the coverage of the Brazilian National Newborn Screening Program, however these changes occurred only after $2001^{(2)}$, leaving gaps in detection in previous years.

This advance in public policies for patients with SCD highlights the milestone in reducing child and youth morbidity and mortality, but it is still necessary to strengthen the actions established by the Ministry of Health, in order to expand permanent multidisciplinary education in the Health Care Network, integrating effectively the human and material resources already existing for the areas of education, involving universities, schools, access to rights, and the community itself (non-governmental associations) so that the SCD becomes more and more known and the patients are better served in full(17).

In the face of this chronic condition, parents organize and seek mutual care perspectives through mutuality; management behaviors centered on the maintenance and quality of life of the child. In this way, the families accessed some support outside the home, for this reason they presented the partnership with the educational centers as a philosophy for management, since the child spends part of the day in these spaces. Although there are concerns about delegating and extending care beyond the family, it is necessary to establish this relationship for effective management ${ }^{(18)}$.

In this study, all children and their families had sickness benefit, and in a family with both children with the disease, the benefit was granted only to one of the children; another family obtained disability retirement for their daughter. Law 8.742 of December 7, 1993 highlights the guarantee of monthly benefit to the person with hereditary disease associated with racial factors, including SCDand other hemoglobinopathies between diseases ${ }^{(2)}$. However, one of the barriers to access this right is related to the employment relationship of the parents, all children benefited have parents who work informally, which predisposes even more financial difficulties.

It was noticed that the families' management behaviors changed over time according to the symptoms, complications and care demands presented by the children. The strategies for the therapeutic follow-up of these families are linked to elective consultations in the blood center, carrying out tests, adequate food and hydration, preventing exposure to extremes of temperature and the use of medications. This care routine overloads the family system, especially the mother of children, who ends up taking over this care more intensely in relation to other family members. This can also reflect on a low quality of life for this caregiver, as shown by studies $(3,15,19)$.

However, along their trajectories, these families acquired skills and became resilient in the face of the challenges of chronic disease ${ }^{(18-20)}$. In this context, the importance of multidisciplinary care to these families stands out, nurses have the competence to plan interventions, and to point out preventive and promotional care strategies at home that can favor the continuity of assistance to children with $\mathrm{SCD}^{(6,21)}$.

In family experiences, perceived consequences were identified, a daily management centered on the sick child, with care being incorporated into the family's routine, even in the face of the adversities caused by the chronic condition. Thus, strategic resources for management are conducted, giving the child a pleasant and healthy environment ${ }^{(10)}$.

The future expectations of families in relation to their children are permeated by doubts and uncertainties, and regardless of the difficulties experienced, they all value the children's quality of life, encouraging them to self-care. Moreover, the family, especially the primary caregiver, performs problem solving skills together with the child, which favors the child's stimulus and interest in controlling his own disease ${ }^{(22)}$.

Issues related to genetic inheritance emerged as one of the families' concerns about the future. It is worth mentioning that children with SCD can suffer the stigma of the disease within their own family, as well as in social spaces such as schools, because for those who are unaware of the disease, they can imagine the disease as contagious making the child feel different in the environment in which he lives and lives ${ }^{(23)}$.

Moreover, another challenging aspect is the transition from child to adolescence. There is a fear by families that these adolescents do not follow the therapeutic regimen correctly, and still have problems of insertion in programs aimed at adult health ${ }^{(24)}$. However, this fact favors rethinking the performance of health professionals, who need to create strategies that involve adolescents with SCD in planning and solving their problems, in order to achieve self-efficacy of treatment and a better quality of life ${ }^{(25)}$. 
Given the ambiguity of feelings that oscillate between fear and hope, we find protective factors against the stress caused by this chronic disease, highlighting faith and spirituality as elements that help in the process of acceptance and adjustment. In a study on the spirituality of families of adolescents with $\mathrm{SCD}^{(26)}$, it was identified that trust in God and prayers were fundamental for relief during sickle cell crises, in addition to favoring coping to overcome the current and expected unpredictability for the future.

SCD, as a chronic condition, requires adaptations and readaptations, being a dynamic process marked by daily advances and challenges, where each family studied acquired their own management styles in their experiences, as seen in a survey of families who experienced liver transplantation of their children ${ }^{(27)}$. Among the families investigated here, three management styles were identified: five families in the accommodatingstyle, in which family members remain focused on seeking normality and adjustment, although they fear about the possible complications of the disease; two families in the strugglingstyle, in which family members live with parental conflict, making management difficult; and only one enduring-style family, in which family members share decisions, believe in their management skills, but over-protect their child.

In the struggling management style, in relation to the implications and potentialities, the family stands out seeking normality, creating mechanisms that overcome the child's vulnerability due to the disease condition. Conflicts can challenge the family to improve skills and develop resources, since stress factors can be potential stimulators of competencies.

Regarding the accommodatingmanagement style, families seek to identify obstacles and potential for the development of healthy functioning, that is, they maintain a routine that seeks balance in all aspects of family life, especially in relation to social life. However, they do not stop worrying about care, to avoid sickle cell crises.

Regarding the family with the enduringmanagement style, the chronic disease condition was not revealed to the child, constituting a great challenge for this family in relation to making the decision on what will be the best time to tell. The main potential is that family members have confidence in their management skills.

It is noteworthy that regardless of the family management style, the key is to facilitate communication in order to explore the various points of view of family members, allowing information to circulate, thus identifying aspects that reveal difficulties, conflicts and potential.

In view of the family management styles found, it was noted that empowerment was a key aspect in the acquisition of skills and abilities for child care. From the perspective of managing chronic disease, empowering the family to play an active role in child care should be the focus of nursing actions with the families of children with SCD, to ensure access at all levels of health care, contributing to the reduction of morbidity and mortality in children with SCD.

Future research in this area should explore the perspective of children with SCD to better understand the family experience. Adaptations in the FMSF to include the perspective of children with chronic conditions have recently been proposed ${ }^{(28)}$.

\section{Study limitations}

This study was conducted with a specific group of families with SCD who live in the same country and state, with similar cultural characteristics. This fact prevents the generalization of the results.

\section{Contributions to the area of nursing, health and public policies}

In this study, it was not possible to make generalizations about the family management of children with SCD in different regions and cultures. However, the data enabled the knowledge of the experiences of these families and possible actions of nurses for comprehensive care, revealing the need to produce nursing research with families of children in these conditions.

\section{FINAL CONSIDERATIONS}

Family management experience knowledge of children with SCD supported the reflection on possible proposals for nurses interventions, such as guidance and support for newly diagnosed families, as, upon receiving the diagnosis, they begin to experience difficulties in accepting and understanding the disease, in addition to the fear of when the child will have the first crisis, and about the care to be provided at home, or in an Emergency Unit. With these situations, it is believed that nurses, as well as the multidisciplinary team, can create projects within the scope of Primary Health Care, in order to ensure a closer relationship with these families through the Family Health Strategy teams, strengthening and supporting the family nucleus for coping and empowerment, thus avoiding the worsening of crises and hospitalizations.

In addition to the guidelines provided by blood centers, it is important that the Health Care Network can provide training for all professionals, facilitating communication and coordination between services so that the promotion, prevention and rehabilitation of children with SCD is more effective. This study showed the need for these actions, alerting for the continuity of care that is expanded and supported by the Health Care Network.

\section{REFERENCES}

1. Chakravorty S, Williams TN. Sickle cell disease: a neglected chronic disease of increasing global health importance. Arch Dis Child.2015;100:48-53. doi:10.1136/archdischild-2013-303773

2. Ministério da Saúde (BR). Secretaria de Atenção à Saúde. Doença Falciforme: Diretrizes Básicas da Linha de Cuidado [Internet]. Brasília: Ministério da Saúde; 2015 [cited 2017 Oct 25]. Available from: http://bvsms.saude.gov.br/bvs/publicacoes/doenca_falciforme_diretrizes_ basicas_linha_cuidado.pdf

3. Hildenbrand AK, Barakat LP, Alderfer MA, Marsac ML. Coping and coping assistance among children with sickle cell disease and their parents. J Pediatr Hematol Oncol. 2015;37(1):25-34. doi: 10.1097/MPH.0000000000000092 
4. Glukman E, Cappelli B, Bernaudin F, Labopin M, Volt F, Carreras J, et al. Sickle cell disease: an international survey of results of HLA-identical sibling hematopoietic stem cell transplantation. Blood. 2017;129(11):1548-56. doi: 10.1182/blood-2016-10-745711

5. Knafl KA, Deatrick J, Havill NL. Continued development of the Family Management Style Framework. J Fam Nurs. 2012;18(1):11-34. doi: $10.1177 / 1074840711427294$

6. Gesteira ECR, Bousso RS, Misko MD, Ichikawa CRF, Oliveira PP. Families of children with sickle cell disease: an integrative review. Online Braz J Nurs. 2016;15(2):276-90. doi: 10.17665/1676-4285.20165289

7. Yin RK. Estudo de Caso: planejamento e métodos. 5 ed. Porto Alegre: Bookman; 2015.

8. Fontanella BJB, Luchesi BM, Saidel MGB, Ricas J, Turato ER, Melo DG. Sampling in qualitative research: a proposal for procedures to detect theoretical saturation. Cad Saúde Pública. 2011;27(2):389-94. doi: 10.1590/S0102-311X2011000200020

9. Fereday J, Muir-Cochrane E. Demonstrating rigor using thematic analysis: a hybrid approach of inductive and deductive coding and theme development. Int J Qualit Methods. 2006;5(1):01-11. doi: 10.1177/160940690600500107

10. Salvador MS, Gomes GC, Oliveira PK, Gomes VLO, Busanello J, Xavier DM. Strategies of families in the care of children with chronic diseases. Texto Contexto Enferm. 2015; 24(3): 662-9.doi:10.1590/0104-07072015000300014

11. Castellanos MEP, Barros NF, Coelho SS. Biographical ruptures and flows in the family experience and trajectory of children with cystic fibrosis. CiêncSaúde Colet. 2018; 23( 2): 357-368.doi:10.1590/1413-81232018232.16252017.

12. Lebensburger JD, Grosse SD, Altice JL, Thierry JM, Ivankova NV. Understanding and improving health education among first-time parents of infants with sickle cell anemia in Alabama: a mixed methods approach. J Pediatr Hematol Oncol. 2015;37(1):35-42. doi:10.1097/ MPH.0000000000000217

13. Silva MEA, Reichert APS, Souza SAF, Pimenta EAG, Collet N. Chronic disease in childhood andadolescence: family bondsin the healthcare network. Texto Contexto Enferm. 2018;27(2):1-11.doi:10.1590/0104-070720180004460016

14. Oliveira PP, Gesteira ECR, Rodarte AC, Costa MA, Amaral JL, Santos WJ. Avaliação de famílias de crianças com doença falciforme. Investig Enferm: Imag Desarrol. 2018;20(2):1-11. doi: 10.11144/Javeriana.ie20-2.afcd

15. Madani BM, Raddadi RAL, Jaoni SAL, Omer M, Awa MIAL. Quality of life among caregivers of sickle cell disease patients: a cross sectional study. Health Qual Life Outcomes. 2018;16(176):1-9. doi: 10.1186/s12955-018-1009-5

16. Lughetti L, Bigi E, Venturelli D. Novel insights in the management of sickle cell disease in childhood. World J Clin Pediatr. 2016;5(1):25-34. doi:10.5409/wjcp.v5.i1.25

17. Mburu J, Odamel. Sickle cell disease: Reducing the global disease burden. Int J Lab Hematol. 2019;1(1):82-8. doi: 10.1111/ijlh.13023

18. Bray L, Shaw NJ, Snodin J. Living and managing with the long-term implications of neonatal chronic lung disease: the experiences and perspectives of children and their parents. Heart Lung. 2015;44(6):512-6. doi: 10.1016/j.hrtIng.2015.08.002

19. Woodson KD, Thakkar S, Burbage M, Kichler J, Nabors L. Children with chronic illnesses: factors influencing family hardiness. Issues Compr Pediatr Nurs. 2015;38:57-69. doi: 10.3109/01460862.2014.988896

20. Mendes-Castillo AMC, Bousso RS, Sloand E. The family management styles framework as a tool for tailoring interventions for pediatric transplant recipients and their families: a case study. Compr Child Adolesc Nurs. 2016;40(1):39-52. doi: 10.1080/24694193.2016.1245364

21. Nóbrega VM, Silva MEA, Fernandes LTB, Viera CS, Reichert APS, Collet N. Chronic disease in childhood and adolescence: continuity of care in the Health Care Network. Rev Esc Enferm USP. 2017;51:e03226. doi: 10.1590/s1980-220x2016042503226

22. Fernandes LTB, Nóbrega VM, Silva MEA, Machado NA, Collet N. Supported self-care for children and adolescents with chronic disease and their families. Rev Bras Enferm. 2017;70(6):1318-29. doi: 10.1590/0034-7167-2016-0553

23. Wesley KM, Zhao M, Carroll Y, Porter JS. Caregiver perspectives of stigma associated with sickle cell disease in adolescents. J Pediatr Nurs. 2016; 31(1):55-63. doi: 10.1016/j.pedn.2015.09.011

24. Kayle M, Tanabe P, Shah NR, Baker-Ward L, Docherty SL. Challenges in shifting management responsibility from parents to adolescents with sickle cell disease. J Pediatr Nurs. 2016;31(6):678-90. doi: 10.1016/j.pedn.2016.06.008

25. Crosby LE, Joffe NE, Peugh J, Ware RE, Britto MT. Pilot of the Chronic Disease Self Management Program for adolescents and young adults with sickle cell disease. J Adolesc Health. 2017;60(1):120-3. doi: 10.1016/j.jadohealth.2016.08.022

26. Clayton-Jones D, Haglund K, Belknap RA, Schaefer J, Thompson AA. Spirituality and religiosity in adolescents living with sickle cell disease. West J Nurs Res. 2016;38(6):686-703. doi: 10.1177\%2F0193945915625065

27. Mendes-Castillo AMC, Bousso RS, Santos MR, Damião EBC. Family management styles: a possibility of evaluation in pediatric liver transplant. Acta Paul Enferm. 2012;25:867-72. doi: 10.1590/S0103-21002012000600007

28. Beacham BL, Deatrick JA. Adapting the Family Management Styles Framework to Include Children. J Pediatr Nurs. 2019;45:26-36. doi: 10.1016/j.pedn.2018.12.006 